\title{
The Public Services of PT KAI in the New-Normal Era
}

\author{
Mira Veranita ${ }^{\mathbf{1},}$, Eki Dudi Darmawan ${ }^{3}$ \\ \{mirave2198@gmail.com ${ }^{1,2}$ \} \\ Politeknik Piksi Ganesha ${ }^{1}$ \\ Universitas Pasundan ${ }^{2}$ \\ Universitas Islam Nusantara ${ }^{3}$
}

\begin{abstract}
The new normal policy with the implementation of health protocols which aims to prevent the spread of the Covid-19 virus has limited access to public services for PT KAI, especially for passenger train services, whose occupancy has been drastically reduced and has decreased its income by $38.9 \%$. To provide prime public services, PT KAI must adapt to accommodate the public's needs for train transportation whilst still paying attention to passenger satisfaction by paying attention to safety and comfortability of passengers. This research method is literature study, using descriptive analysis, namely providing education and understanding to readers. The type of data used in this study is secondary data.The results show that PT KAI has implemented service standards in accordance with the Circular of the Ministry of Transportation Number 14 of 2020 concerning technical instructions for railroad transportation control during the adaptation period for new habits to prevent the spread of Covid-19 which includes: operation of rail travel, passenger capacity and health protocols in which the requirements for passengers and operators of railway infrastructure and facilities are regulated. The results of this study also reveal that there is still a lack of public awareness in adhering to health protocols, however PT KAI always conducts regular education, socialization and simulation of SOP Health Protocols to the public, service users and employees of PT KAI.
\end{abstract}

Keywords: Public service, PT. KAI, new normal

\section{Introduction}

The current COVID-19 pandemic has a significant impact on social life. Social distancing, physical distancing and large-scale social distancing (PSBB) policies were made to reduce the chain of virus spread. "Lockdown policy is not the only government strategy to tackle coronavirus, social distancing policy is also implemented to tackle coronavirus for areas where the spread of coronavirus is not yet massive. Herdiana [1] said that : The basis of understanding on social distancing policy is by reducing the intensity of social interaction between people, which in the implementation of social distancing policy, direct physical contact between one person and another is limited so that the spread of the coronavirus can be minimized among humans. People are asked not to gather in groups and avoid crowded places. The habit of washing hands with soap for twenty minutes regularly and the use of masks, especially in public places, are mandatory protocols in this new normal era. Not only protect yourself but also others.

To prevent the spread of the virus, the Minister of Health issued Permenkes No.9 / 2020 on Guidelines for Large-Scale Social Restrictions to accelerate the handling Covid-19 and it is 
implemented in several regions in Indonesia. These regulations cover school and work holidays, restrictions on religious activities, restrictions on activities in public places or facilities, restrictions on social and cultural activities, restrictions on modes of transportation, and restrictions on other activities. The state civil apparatus (ASN) which serves as public servants also implements a work from home (WFH) work system.

Aknolt Kristian Pakpahan [2] in his research explained that: The report of the Organization for Economic Co-operation and Development (OECD) states that this pandemic has implications for the threat of a major economic crisis marked by the cessation of production activities in many countries, falling levels of public consumption, loss of consumer confidence, fall in the stock market which in turn leads to uncertainty. If this continues, the OECD predicts a decline in output levels of between a fifth and a quarter in many countries, with consumer spending potentially falling by about a third.

"The Covid-19 pandemic has an impact on the worsening of the financial system, which is reflected in the decline in domestic economic activity. The government and related institutions need to immediately take policies and steps to save the national economy and financial system stability and economic recovery and strengthen the authority of various institutions in the financial sector [3]. However, services must still be provided to people who desperately need rail transportation. It is time for PT KAI to implement a new normal service and fulfill the public's need for railroad transportation while still paying attention to safety, comfort and passenger safety.

The new normal policy by implementing health protocols has limited access to public services for PT KAI. PT KAI must try to serve the public maximally and switch to an online system. This transition effort must be accompanied by providing education and socialization on a massive scale to all elements of society who will access public services to take advantage of the online system in every public service to be accessed so that public services in the midst of a new "new normal" life order are not disrupted and become more effective. and efficient.

The implementation of health protocols with restrictions on the movement of people by the government will have a direct impact on the community, including the public service sector organized by state administrators that provide direct services to the public. The Covid-19 pandemic has had an impact on the worsening of the financial system as indicated by a decline in domestic economic activity.

\section{Methods}

This qualitative research uses the case method, to reveal and understand the realities that occur in the field intensively, in detail and comprehensively. The data collection techniques used were literature studies, interviews and documentation studies, through various literatures, namely scientific journals, books, data from PT KAI, articles in mass media, and statistical data, accompanied by interviews with PT KAI users in this new normal era. This research is a descriptive analysis, which is to provide education and understanding to readers, using secondary data. 


\section{Results and Discussion}

PT KAI (Persero) is an Indonesian State-Owned Enterprise that provides railroad transportation services which include passenger and freight transportation. At the end of March 2007, the DPR passed the revision of Law Number 13 Year 1992, namely Law Number 23 Year 2007 which emphasizes that private and regional government investors are given the opportunity to manage rail transport services. Thus, the enactment of this law legally ends the monopoly of PT KAI in operating railways in Indonesia. On August 12, 2008, PT KAI separated the Jabotabek Urban Transport Division into PT KAI Commuter Jabodetabek (KCJ) which in 2017 became PT Kereta Commuter Indonesia to manage commuting trains in the Jakarta and surrounding areas. During 2015, the number of train passengers reached 325.94 million. On September 28, 2011, to coincide with its 66th birthday, PT KAI launched a new logo.

PT KAI at the regional level has nine Operational Areas (Daop) in Java and three Regional Divisions (DIVRE) in Sumatra. One of the operating areas that has the largest station with the highest number of passengers is the operation area II, namely Bandung Station. Operation Area II Bandung or abbreviated as Daop II Bandung is one of the Indonesian railway operating areas, under the PT Kereta Api Indonesia (Persero) environment.

Based on BPS data, during the COVID-19 Pandemic, the number of domestic and international transport passengers experienced a sharp decline. For air transportation, the number of passengers decreased by $20.84 \%$, while for sea transportation it was down $3.78 \%$ from the previous month. It is the same as PT KAI, which has also experienced a significant impact both on the number of passengers and income as a result of the Covid-19 pandemic. Some services, such as long-distance train travel, have to be temporarily suspended and their operations restricted. Since March 23, 2020, PT KAI has canceled 401 train trips. This is done to support government directives regarding the prohibition of homecoming activities. In addition, the number of passengers that can be transported during this pandemic has also been adjusted to only around 60 people per car from a capacity of 200 people per car to comply with the Covid-19 protocol. Below in Table 1 that describes the comparison of the number of train passengers of PT KAI from January to September 2020. A drastic difference began in April 2020 which touched its lowest figure in May 2020 with a total passenger number of 406,944 people. In June, the number of passengers again gradually increased until the end of September through the figure of 1,751,318 passengers (see Table 1).

Table 1. Comparison of number of passengers during 2020

\begin{tabular}{|c|c|}
\hline Month/ 2020 & Vol PNP \\
\hline Jan & 7.400 .752 \\
\hline Feb & 6.669 .659 \\
\hline Mar & 4.878 .223 \\
\hline Apr & 761.362 \\
\hline Mei & 406.944 \\
\hline Jun & 699.309 \\
\hline Jul & 1.122 .357 \\
\hline Agt & 1.759 .751 \\
\hline Sept & 1.751 .318 \\
\hline Total until september & 25.449 .675 \\
\hline
\end{tabular}




\subsection{New normal transition standard service}

Of all the services offered by PT KAI, the one most affected by the Covid-19 condition was a passenger train whose occupancy was drastically reduced and made PT KAI's income drop drastically. PT KAI sells its tickets on www.kai.id and the KAI Access application which can be downloaded on the Playstore/Appstore. For the price range set by PT KAI varies greatly, because it is influenced by several factors, namely the distance traveled and the selected class (economy or executive), with prices ranging from:

- Executive class: Rp. 200,000 - Rp. 600,000

- Economy class: IDR 50,000 - IDR 200,000

- Local trains (KRD): Rp. 8,000 - Rp. 36,000

In the midst of this pandemic, the train ticket prices offered have increased because there are still only a few trains operated and PT KAI is experiencing a deficit in revenue. PT KAI stations are located in all corners of Java and Sumatra, so that they are easily accessible by the community, this has resulted in the train becoming the most popular transportation service for the community. But lately, these stations have been very quiet due to health protocol regulations that impose social distancing and temporary suspension of train services.

The promotions carried out by PT KAI are quite diverse, through print media, through print media, social media, advertising, sales promotion, and personal selling through the distribution of train schedules using various media. PT KAI also carries out sales promotions using digital marketing by utilizing applications and online ticket sales. PT KAI recorded revenues of Rp7.41 trillion in the second quarter of 2020, which fell 38.9\% compared to the same period in 2019. During the first 6 months of 2020, PT KAI recorded an accumulated loss of Rp1.35 trillion, inversely proportional to the period that was the same as the previous year where PT KAI recorded an accumulated profit of IDR 1.21 trillion. (source www.kai.id) This is none other than the result of the temporary stop and restrictions on train operations in March-April 2020 when the beginning of COVID-19 spread in Indonesia.

Since June-July 2020, PT KAI has started to reopen train operations for the general public, gradually starting from short and medium-distance trains. This opening was certainly accompanied by various new regulations related to the health and safety of passengers and employees of PT KAI. New Normal in trains prioritizes railway services by reducing physical contact and implementing health protocols. The point is to protect employees and passengers from the possibility of being exposed to Covid-19 during the New Normal period as follows:

Booking Long Distance Train tickets can only be made online through the KAI Access application and other external channels, by including the complete documents required according to the Covid-19 Task Force Circular, Number 7 of 2020, which shows a PCR Test Certificate with negative results valid for 7 days or a certificate of Rapid Test with non-reactive results that is valid for 3 days at the time of departure. In addition, showing a symptom-free certificate such as influenza issued by a hospital doctor / puskesmas for areas that do not have PCR or Rapid Test facilities. Passengers must also download and activate the Peduli Lindungi application on the mobile device. The counters at the station are only used for go show purchases (three hours before the scheduled departure), and still pay attention to health protocols by keeping a distance. The operating hours of the trains are regulated by taking into account the PSBB in each region. In the Figure 1 are the conditions for purchasing tickets both online and offline at the Train Station. 


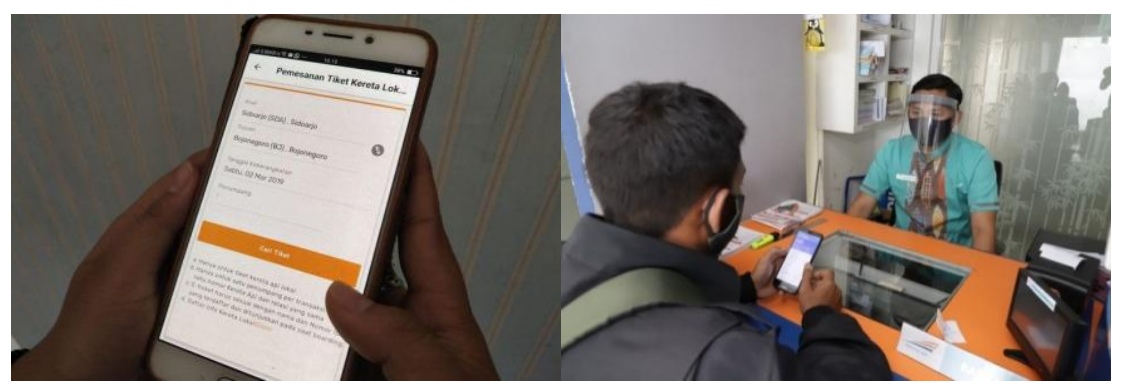

Fig. 1. Online and offline ticket booking

Pre-trip in zone 3 of the departure station, passengers are advised to bring hand sanitizers, wear a nose and mouth mask and wash their hands in the space provided.

The implementation of CLM at Gambir station also makes it easier and more attractive to increase the number of return passengers. CLM or Corona Likehood Metric which can be easily downloaded on the play store or app store is very efficient and effective, when compared to SIKM or the Entry and Exit Permit. This is because CLM is paperless and eliminates bureaucracy, because it is easy to do with an android or a cellphone owned by a passenger.

The determination of passenger capacity must comply with the health protocol as stipulated as follows, in the first stage, a maximum number of passengers is limited to $70 \%$ (seventy percent) of the number of seats of each train capacity. Especially for Luxury trains, the maximum passenger capacity is $100 \%$, while the second stage is to limit the number of passengers to a maximum of $80 \%$ (eighty percent) of the number of seats of each train capacity.

When leaving, passengers must show their tickets and identity to the boarding officer. If it has been checked, the passenger scans the ticket barcode or e-boarding independently witnessed by the boarding officer. Passengers are required to maintain a distance according to the seating and standing signs at the station and on the train, wear a mask, passengers are also required to wear a face shield provided by KAI, as well as a protective coat (jacket or long-sleeved clothing). All equipment must be used by passengers from the time they are at the station until they leave the arrival station area.

In the Figure 2 is an overview of the health protocol carried out by PT KAI before entering the station area and entering the train.

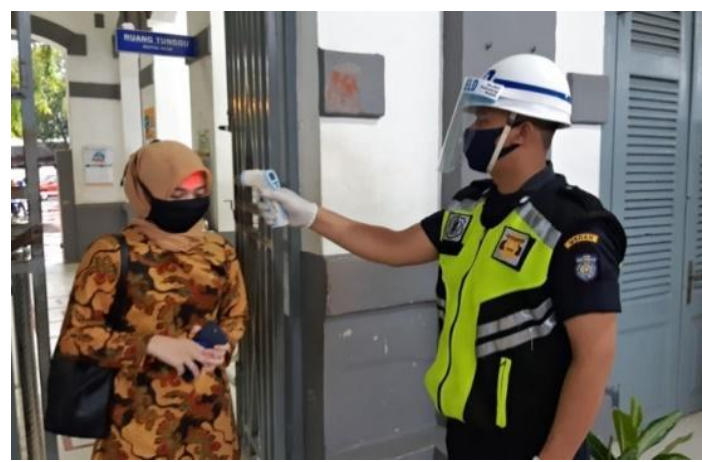

Fig. 2. Check temperature, mask, face shield 
To ensure passenger health, officers will measure the body temperature of passengers on the train every three hours. If a passenger is caught with a temperature of 37.3 degrees Celsius or more and experiences Covid-19 symptoms, the passenger will be moved to an isolation room on the train.

PT KAI also regulates the operators of railway infrastructure and facilities by: Providing hand sanitizers and hand washing facilities, providing face shields; providing mask sales counters at affordable prices at stations, providing distance guard facilities ( 1 meter) in the form of signs at stations and on trains, providing applications or queuing number systems, providing isolation space if there are passengers whose temperature is not normal, providing medical personnel and emergency teams at stations and / or on every train journey, Cleaning facilities that passengers frequently touch with disinfectants by OTC officers (30 minutes), separating passengers over 50 years / elderly from other passengers

The officer will clean the objects that are often held by hand every 30 minutes in turn. Train officers will be equipped with personal protective equipment (PPE). KAI provides portable sinks and hand sanitizers at points that are easily accessible by passengers.

The Figure 3 below shows the cleaning process carried out by PT KAI officers
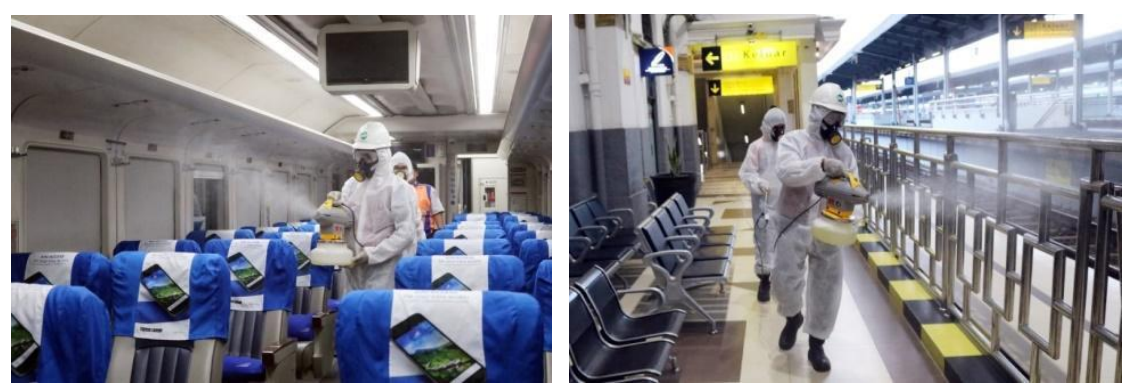

Fig. 3. Cleaning of carriages and station locations

To maintain the safety and health of KAI frontliners who have the potential to have close contact with passengers, they will be provided with personal protective equipment (PPE) in the form of masks, gloves and face shields, and station cleaners regularly clean or sterilize station areas that are touched by passengers such as chairs, door handles and others.

PT KAI also prepares Standard Operating Procedures for Emergency Management SOPs, if a passenger is exposed to Covid-19, or by dropping off a passenger at the nearest station if Covid-19 is indicated.

PT KAI always tries to improve its operational services during this pandemic, because in Indonesia positive cases of Covid-19 are still increasing every day. It is very important to improve security and health services for prospective passengers who are supported by information technology innovation because of the less mobility factor and developments in the online world that have increased dramatically.

PT KAI must adjust its marketing strategy and ensure that the company uses good online services and is not left behind. In addition, the socialization of the use of sophisticated information technology by PT. The massive KAI can significantly increase the number of passengers, given the productive age of the Indonesian population currently using smartphones and actively using social media. 


\section{Conclusion and Recommendation}

\subsection{Conclusion}

At the time of writing this article, PT KAI has implemented service standards in accordance with the Circular of the Ministry of Transportation Number 14 of 2020 concerning technical instructions for railroad transportation control during the adaptation period of new habits to prevent the spread of COVID-19 which includes: train travel operations, passenger capacity and protocols. health, which includes the regulation of requirements for passengers and operators of railway infrastructure and facilities.

The results of this study also reveal that there is still a lack of public awareness in complying with health protocols, but PT KAI always conducts regular education, socialization and simulation of SOP Health Protocols both to the public, service users and employees of PT KAI, especially in the use of the CLM application or Corona Likelihood Matrix through passenger hand phones at PT KAI stations.

\subsection{Recommendation}

a. PT KAI's massive socialization with the help of social media such as Instagram, Youtube and spotify will significantly increase PT KAI's users.

b. Online payments are enhanced by cooperating with private channels such as Gopay, pedia stores and others, making it very easy and attractive to potential customers. Even with Bumdes and banks that have cooperation with ASN salaries.

c. Socialization with cookie techniques can also be done for customers in the middle and upper economy.

d. The cash back program will also add to the attractiveness of train ticket sales.

e. To increase the market expansion when the fast train is ready, the Covid protocol must be maintained so that the service is more attractive to customers of the existing types of trains, for example the quality of the menu in restoration is improved, the friendliness of all PT KAI employees at every stations and at all levels not only at Gambir big station and other big stations.

\section{References}

[1] D. Herdiana, "Social Distancing: Indonesian Policy Reponse To The Corona Virus Disea 2019 (Covid19)," J. Ilmu Adm., vol. 17, no. 1, pp. 93-110, 2020.

[2] A. K. Pakpahan, “COVID-19 dan Implikasi Bagi Usaha Mikro, Kecil, dan Menengah,” J. Ilm. Hub. Int. Pacis, vol. 20, no. April, 2020.

[3] Syafrida, "Bersama Melawan Virus Covid 19 di Indonesia," J. Sos. Syar-i FSH UIN Syarif Hidayatullah, vol. 7, no. 6, pp. 495-508, 2020.

[4] Keputusan Menteri Negara Pemberdayaan Aparatur Negara Nomor 63/ KEP/M.PAN/7/2003 Tentang Pedoman Umum Penyelenggaraan Pelayanan Publik.

[5] Keputusan Menteri Negara Pemberdayaan Aparatur Negara Nomor 63/ KEP/M.PAN/7/2003 Tentang Pedoman Umum Penyelenggaraan Pelayanan Publik. 